\title{
Can Bradyrhizobium strains inoculation reduce water deficit effects on peanuts?
}

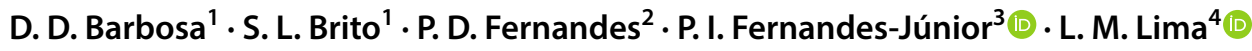

Received: 27 February 2018 / Accepted: 5 June 2018

(c) Springer Nature B.V. 2018

\begin{abstract}
Drought is one of the environmental factors that most affects peanut cultivation in semi-arid regions, resulting in economic losses to growers. However, growth promoting bacteria are able to reduce water deficit damage in some plant species. In this context, this study aimed to evaluate the interaction of Bradyrhizobium strains reducing water stress effects on peanut genotypes by antioxidant enzymes activities, leaf gas exchanges and vegetative growth, as well as to determine the taxonomic positioning of strain ESA 123. The 16S rRNA gene of ESA 123 was amplified by PCR and sequenced by dideoxy Sanger sequencing method. An experiment was performed in greenhouse with three peanut genotypes (BRS Havana, CNPA 76 AM and 2012-4), two Bradyrhizobium strains (SEMIA 6144 and ESA 123), a mineral source of N and an absolute control (without $\mathrm{N}$ ) under two water regimes (with and without irrigation). Seeds of peanut were sown and the plants were grown until 30 days after emergence. On the 20th day, the water deficit plants group had their irrigation suspended for 10 days. At in silico analyzes, ESA 123 presented 98.97\% similarity with the type strain of B. kavangense. Leaf gas exchange was affected by water deficit; as well as alteration of antioxidant activities and reduction of vegetative growth variables. However, some plants inoculated with SEMIA 6144 and ESA 123 strains presented lower reductions and increment of some evaluated variables, mainly the ones inoculated with the ESA 123 strain, Bradyrhizobium sp. from the semi-arid region of Northeast Brazil. This data suggests beneficial effects of the peanut-Bradyrhizobium interaction in a water stress condition, specially with the ESA 123 strain.
\end{abstract}

Keywords Antioxidant enzymes $\cdot$ Drought tolerance $\cdot$ Leaf gas exchanges $\cdot$ Rhizobia $\cdot$ Inoculant

P. I. Fernandes-Júnior paulo.ivan@embrapa.br

$\triangle$ L. M. Lima

liziane.lima@embrapa.br

1 Programa de Pós-Graduação em Ciências Agrárias, Universidade Estadual da Paraíba, Rua Baraúnas, 351, Universitário, Campina Grande, PB, Brazil

2 Departamento de Agroecologia, Universidade Estadual da Paraíba, Rua Baraúnas, 351, Universitário, Campina Grande, PB, Brazil

3 Embrapa Semiárido, BR 428, Km 152, Zona Rural, Petrolina, PE, Brazil

4 Embrapa Algodão, R. Osvaldo Cruz, 1143, Centenário, Campina Grande, PB, Brazil

\section{Introduction}

Water deficit can lead to severe physiologic, biochemical and molecular alterations in plants, resulting in significative losses on crop yield (Farooq et al. 2009). In regions with irregularities in rainfall occurrence and distribution, as the semi-arid Northeast of Brazil, for example, these effects are observed even in crops with certain water stress tolerance, such as peanuts (Arachis hypogaea L.) (Ribeiro 2010).

The semi-arid region of Brazil is an important area of peanut production, standing out as the second in national production, only behind areas of production in São Paulo state (CONAB 2017). Most peanut growers from the semiarid region of northeastern Brazil are family-based farmers, with low-technology in rain-fed agricultural systems. Thus, peanuts cultivation presents economic and social importance to the northeastern region and the development of technologies for the crop production is necessary. 
Over the years, new peanut varieties with water deficit tolerance have been developed in Brazil aiming to reduce the drought effects, a common problem in the Northeastern semi-arid region of the country (Santos et al. 2006). Although there is a significant effort in this area of research, few potential materials have been obtained, which indicates the importance of new strategies to reduce the harmful effects of water stress. One potential strategy to reduce the effects of abiotic stress in peanuts is the biological interaction with rhizobia strains. This interaction may result in the selection of promising macro and micro-symbiont associations, as already shown for cowpea (Oliveira et al. 2012) and common beans (Suárez et al. 2008).

Peanut is able to associate efficiently with different rhizobial strains (Melo et al. 2016), presenting higher efficiency the Bradyrhizobium genus (Valetti et al. 2016; Santos et al. 2017a). During the last years, some studies have been carried out in Brazil aiming to evaluate the biodiversity (Lyra et al. 2013; Torres-Júnior et al. 2014; Santos et al. 2017a), the symbiotic efficiency (Torres-Júnior et al. 2014; Santos et al. 2017a, b), and the agronomic efficiency of new rhizobium strains (Sizenando et al. 2016). However, the potential of these bacteria to reduce the abiotic stresses, as water deficit, for example, has not been investigated. This potential is even more promising when the native bacteria from arid or semiarid regions are evaluated, presenting higher water deficit tolerance (Zahran 1999; Kavamura et al. 2013; Fernandes-Júnior et al. 2015) and may confer some water stress tolerance in crops (Kavamura et al. 2013).

As in other plants, in peanuts also occur severe physiological changes resulting from the reduction of water availability lead to the production of reactive oxygen species (ROS) (Soares and Machado 2007; Barbosa et al. 2014), which act as cellular signals against stress. However, when at a high level, ROS can cause irreversible cellular damage to the cells function, affecting several biomolecules and culminating with cell death (Kim and Kwak 2010). The reduction of ROS is due to several factors, but mainly to different enzymes activities, how superoxide dismutase (SOD), catalase (CAT), and ascorbate peroxidase (APX) the most studied (Maia et al. 2007; Marques et al. 2010; Marin et al. 2010). In experiments testing water stress, the evaluation of these enzymes activities can be used as an inexpensive and efficient tool to select promising treatments to face the water deficit (Chaves and Aidar 2013).

An important function of the symbiotic bacteria is the growth promotion and development of plants. In situations of biotic or abiotic stress, these microorganisms are capable to show several plant stimulation mechanisms, favoring the growth of plants under the stress. Among the mechanisms, the production of trehalose and other, and other osmoregulatory compounds can avoid the excessive loss of water, increasing the plant drought tolerance (Shameer and Prasad 2018).

The ESA 123 strain of Bradyrhizobium sp., native from a soil in the municipality of Barbalha (Ceará, Brazil), has already been indicated as a bacterium with high symbiotic efficiency (Santos et al. 2017a) and agronomic efficiency in different sites of the Brazilian semi-arid region (Sizenando et al. 2016). This strain may present certain drought tolerance since it is from a dry region and is efficient in fixing $\mathrm{N}$ in association with peanut. Although it was isolated and preliminarily classified as Bradyrhizobium sp., the taxonomic position of this strain is still uncertain and needs to be determined.

The inoculation of efficient diazotrophic bacteria can alter the activity of oxidative stress enzymes and the expression of related genes in plants under water stress (Fukami et al. 2017b), in addition to other physiological traits. Despite the symbiotic and agronomic potential of the strains ESA 123 from Bradyrhizobium sp. and SEMIA 6144 from B. elkanii (strain used in commercial peanut inoculants), the symbiotic efficiency and the ability to influence the peanut physiology under water deficit has not been evaluated.

Thus, we hypothesized that the inoculation of efficient Bradyrhizobium strains may increase the tolerance of peanut genotypes under water deficit. The aim of this study was to evaluate the effect of Bradyrhizobium strains inoculation (Bradyrhizobium sp. ESA 123 and B. elkanii SEMIA 6144) on the physiological and biometric characteristics of peanut plants submitted to water stress, as well as to determine the taxonomic positioning of strain ESA 123 with the aid of $16 \mathrm{~S}$ rRNA gene sequence analysis.

\section{Materials and methods}

\section{Identification of ESA 123 by analysis of 16S rRNA gene sequence}

Bacteria ESA 123 was grown in liquid YM medium (Vincent 1970) without bromothymol blue for 5 days. One milliliter of the bacterial broth was used for DNA extraction with the Wizard Genomic DNA Extraction kit (Promega, USA), following the manufacturer instructions. For 16S rRNA gene amplification, we used the universal primers 27F (AGAGTT TGATCMTGGCTCAG) and 1492R (TACGGYTACCTT GTTACGACTT) (Weisburg et al. 1991). PCR reactions were adjusted to $30 \mu \mathrm{L}\left(1 \times\right.$ reaction buffer, $2.0 \mathrm{mmol} \mathrm{L}^{-1}$ of $\mathrm{MgCl}_{2}, 0.25 \mathrm{mmol} \mathrm{L}^{-1}$ of each dNTP, $1 \mathrm{U}$ of Taq DNA polymerase and $0.25 \mu \mathrm{mol} \mathrm{L}{ }^{-1}$ of each primer). The reactions were performed in a Veriti 96-well thermocycler (Applied Biosystems, USA), applying 4-min initial denaturation step at $94{ }^{\circ} \mathrm{C}$, followed by 35 cycles of denaturation $\left(94^{\circ} \mathrm{C}\right.$ for 1-min), annealing $\left(60^{\circ} \mathrm{C}\right.$ for $\left.45 \mathrm{~s}\right)$, and extension $\left(72{ }^{\circ} \mathrm{C}\right.$ for 
2 min) and a final extension step of $72{ }^{\circ} \mathrm{C}$ for 5 -min. The amplifications success was verified by horizontal electrophoresis in a $0.8 \%(\mathrm{w} / \mathrm{v})$ agarose gel in TBE $0.5 \times$ buffer stained with Gel Red (Biotium) and visualized in a UV chamber. The PCR product was purified with Wizard ${ }^{\circledR}$ SV Gel and PCR Clean-Up System (Promega, USA) commercial kit, following manufacturer's instructions.

Sequencing reactions were carried out with both forward and reverse primers in a $3730 x \mathrm{l}$ genetic analyzer (Applied Biosystems, USA) at Macrogen (Seoul, South Korea). The forward and reverse sequences were used to contig assembly using the BioEdit software v 7.0 (http://mbio.ncsu.edu/ BioEdit/bioedit.html). The sequence was deposited in GenBank database (http://www.ncbi.nlm.nih.gov/genbank/) under the accession number MG982490.

For bacterial identification, the 16S rRNA sequence were compared to EzBioCloud database (http://www.ezbio cloud.net) (Yoon et al. 2017). The neighbor-joining phylogenetic tree was constructed using the MEGA software v 6.0 (Tamura et al. 2013). For sequence comparison, the alignment of the obtained sequences and those from databases were carried out. The MUSCLE algorithm was used for alignment and the Jukes-Cantor model were used for the tree construction. Phylogeny was tested by the bootstrap method with 1000 replications.

\section{Water tolerance of peanuts inoculated with Bradyrhizobium}

\section{Experiment set up and conduction}

The experiment was carried out under greenhouse conditions at Embrapa Algodão (Embrapa Cotton) facilities in Campina Grande, PB, Brazil $\left(07^{\circ} 13^{\prime} \mathrm{S}, 53^{\circ} 31^{\prime} \mathrm{W}\right)$ in pots with $32 \mathrm{~L}$ of capacity. As a substrate for plant growth, a sample from the A horizon of a Fluvic Neosol was used, whose fertility characteristics were evaluated according to Embrapa (1997) and presented the following description: $\mathrm{Ca}^{2+} 14.0 \mathrm{mmolc} / \mathrm{dm}^{3}$, $\mathrm{Mg}^{2+} 4.5 \mathrm{mmolc} / \mathrm{dm}^{3}, \mathrm{~K}^{+} 0.1 \mathrm{mmolc} / \mathrm{dm}^{3}$, S $18.6 \mathrm{mmolc} /$ $\mathrm{dm}^{3}, \mathrm{H}+\mathrm{Al} 10.3 \mathrm{mmolc} / \mathrm{dm}^{3}, \mathrm{P} 5.6 \mathrm{mg} / \mathrm{dm}^{3}$ and organic carbon $3.3 \mathrm{~g} / \mathrm{kg}$. According to the soil analysis, each pot was fertilized with $9 \mathrm{~g}$ of simple superphosphate $\left(18 \% \mathrm{P}_{2} \mathrm{O}_{5}\right)$ and $2 \mathrm{~g}$ of potassium chloride $\left(60 \%\right.$ of $\left.\mathrm{K}_{2} \mathrm{O}\right)$ before sowing.

Seeds were previously sanitized with $96^{\circ} \mathrm{GL}$ ethanol for $30 \mathrm{~s}$, followed by an immersion in sodium hypochlorite $(\mathrm{NaClO} 1 \% \mathrm{v} / \mathrm{v})$ for $3 \mathrm{~min}$ and ten successive washes with autoclaved distilled water (Vincent 1970). The evaluated treatments were: inoculation of the ESA 123 strain; inoculation of the SEMIA 6144 strain from B. elkanii, used in the commercial inoculant for peanut; fertilization with ammonium sulfate in a dose equivalent to $80 \mathrm{~kg} \mathrm{~N} \mathrm{ha}^{-1}$; control (without inoculation and fertilization). The evaluated peanut genotypes were BRS Havana and CNPA 76 AM varieties and the advanced lineage 2012-4.

Four seeds were sown per pot and 10 days after emergence (DAE), thinning was performed, leaving only two plants per pot. All plants were daily irrigated with $500 \mathrm{~mL}$ water per pot. On the 20th day after germination, the plants were divided into two groups (with and without stress). The plants under water deficit had their irrigation suspended for 10 days. Plants that were not submitted to the water deficit regime were irrigated daily with $500 \mathrm{~mL}$ water per pot.

\section{Leaf gas exchanges}

Gas leaf exchange evaluations were performed in the morning between 9:00 am and 11:00 am, when the plants under water deficit were under 10 days of irrigation suspension. For the readings an IRGA (Infra Red Gas Analyzer-LcproSD, ADC BioScientific) was used, using atmospheric carbon dioxide and artificial light source of $1200 \mu \mathrm{mol} \mathrm{m}^{-2} \mathrm{~m}^{-1}$. The evaluated parameters were net photosynthesis $(A)$, transpiration $(E)$ and stomatal conductance $(g s)$ (Magalhães Filho et al. 2008).

\section{CAT and APX activity and proline accumulation}

For the biochemical evaluations, the protein extraction was carried out from $0.2 \mathrm{~g}$ of fresh plant material (leaves collected at the end of the experiment) and conditioned at $-80^{\circ} \mathrm{C}$. The leaves were then macerated and $3 \mathrm{~mL}$ of $0.1 \mathrm{M}$ potassium phosphate buffer $\mathrm{pH} 7.0$ containing $100 \mathrm{mM}$ EDTA, $1 \mathrm{mM}$ ascorbic acid and 4\% polyvinylpolypyrrolidone (PVP) were added. Protein content was measured by the Bradford (1976) method. Catalase activity (CAT) was determined according to Azevedo et al. (1998). To determine ascorbate peroxidase (APX) activity, Nakano and Asada (1981) method was used and for free proline content, the methodology described by Bates et al. (1973) was performed.

\section{Vegetative development evaluation}

The vegetative growth evaluated were: plant height $(\mathrm{PH})$ $(\mathrm{cm})$, measured from the base to the apex of the main stem; shoot dry mass (SDM) and root dry mass (RDM) (g), the material was placed in an oven with forced air circulation at $65{ }^{\circ} \mathrm{C}$, for approximately $72 \mathrm{~h}$, until reaching a constant mass. After drying, the material was weighed in a precision balance.

\section{Determination of nitrogen content in the shoots}

The nitrogen content of the shoot (NCS) was determined by the Kjeldahl semi-micro method (Liao 1981). The shoots 
were dried in a forced air circulation oven at $65^{\circ} \mathrm{C}$ for $72 \mathrm{~h}$ and then milled. A sample of $2 \mathrm{mg}$ was subjected to a predigestion with $50 \mathrm{mg}$ of sodium sulfate, $0.5 \mathrm{mg}$ of copper sulfate and $5 \mathrm{~mL}$ of sulfuric acid for $12 \mathrm{~h}$. The solution was heated to $350{ }^{\circ} \mathrm{C}$ until the organic matter was dissolved. To quantify the nitrogen, $1 \mathrm{~mL}$ of the digested extract was placed in a volumetric flask containing $45 \mathrm{~mL}$ deionized water, $1 \mathrm{~mL} 10 \%$ sodium hydroxide, $1 \mathrm{~mL} 10 \%$ sodium silicate, and $2 \mathrm{~mL}$ Nessler reagent, and estimated through spectrophotometry at $410 \mathrm{~nm}$. The nitrogen accumulated in the shoot was calculated by multiplying the $\mathrm{N}$ content by the mass of the shoot.

\section{Statistical analyzes}

The experiment was carried out in a completely randomized design with a 3 (genotypes) $\times 4$ ( 2 Bradyrhizobium spp. as $\mathrm{N}$ sources +1 mineral source of $\mathrm{N}+1$ absolute control $) \times 2$ (water regimes) factorial scheme. The data collected were subjected to analysis of variance (ANOVA) by $\mathrm{F}$ test, followed by means analysis by Tukey test at 0.05 probability level, using Sisvar 5.6 statistical package (Ferreira 2011).

\section{Results}

\section{Analysis of the $16 \mathrm{~S}$ rRNA gene sequence of strain ESA 123}

Obtaining a contig with 1268 bases allowed a good comparison in the EzBiocloud database. In this comparison, the highest similarity of this strain was with $B$. kavangense strain (98.97\% of similarity). Neighbor-joining phylogenetic of
ESA 123 was constructed with Bradyrhizobium type strains published sequences. ESA 123 formed a monophyletic clade with $B$. kavangense and provides stronger evidence that it is the same, or close, species (Fig. 1).

\section{Leaf gas exchanges}

For $A$, we verified that the genotypes under water deficit conditions showed a reduction in the photosynthetic rate (Fig. 2a). However, genotypes BRS Havana and 2012-4 inoculated with strain SEMIA 6144 presented lower reduction in their photosynthetic rate. The genotype 2012-4 also presented smaller reduction of $A$ in the presence of the strain ESA 123. Evaluating $g s$, there was reduction in all the treatments under water restriction, with a reduction of more than $50 \%$ in most treatments when compared to irrigated plants (Fig. 2b). However, it was observed that both SEMIA 6144 and ESA 123 were efficient in maintaining the $g s$, in the BRS Havana and 2012-4 genotypes, rate higher than in treatments without inoculant. $E$ was reduced in all genotypes under water deficit (Fig. 2c). Nonetheless, the genotypes BRS Havana and 2012-4, inoculated with SEMIA 6144, presented a smaller reduction of $E$, compared to the same treatment without water deficit. The CNPA 76 AM and 2012-4 genotypes, supplemented with nitrogen, reduced the $E$ rate by only $70 \%$ when compared to the same treatments without water restriction.

\section{CAT and APX activities and proline accumulation}

There was a reduction in CAT activity in some treatments under water restriction as observed in the genotypes CNPA 76 AM and BRS Havana inoculated with ESA 123 (Table 1).

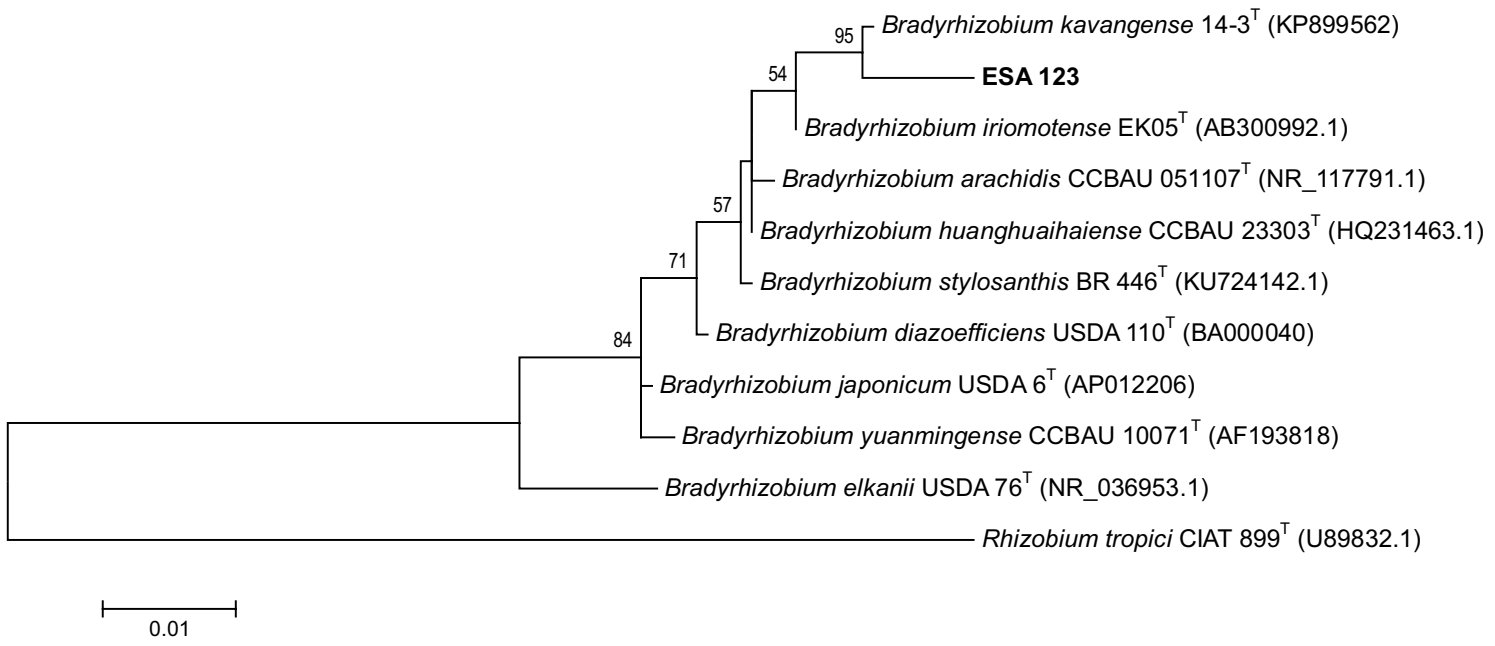

Fig. 1 Neighbor-joining phylogenetic (Jukes-Cantor model) tree based on the near complete 16S rRNA gene sequence (1233 nt) ESA 123 strain from of A. hypogaea and nine type strains of Bradyrhizo- bium. Numbers in the nodes of branches are the bootstrap values from 1000 replications. Bootstrap values lower than $50 \%$ are not shown. Rhizobium tropici CIAT $899^{\mathrm{T}}$ was used as outgroup 
Regarding inoculation with the SEMIA 6144 strain, it was observed an increase of CAT in the CNPA 76 AM, BRS Havana and 2012-4 genotypes of 71, 34 and 62\%, respectively. There was also a significant increase in treatments with and without nitrogen, since in genotype 2012-4 the increase was 106 and 103\%, respectively. In the genotype BRS Havana the increase was $262 \%$ in treatments without nitrogen (Table 1).

APX activity in the genotype CNPA 76 AM increased by $38 \%$ when inoculated with SEMIA 6144 . The genotypes CNPA 76 AM, BRS Havana, and 2012-4 showed a significant reduction of APX enzyme activity when inoculated with the ESA 123 strain, different from the one observed for the treatments of inoculation with the strain SEMIA 6144, since the BRS Havana and 2012-4 genotypes did not present significant alterations in APX activity and the CNPA 76 AM genotype showed an increase in its activity in water restriction condition.

Proline content increased in all treatments under water restriction. For BRS Havana, the inoculants induced the highest proline content, compared to the other treatments, suggesting that this is a characteristic of that genotype.

\section{Vegetative development of plants}

For the growth variables, the reduction of $\mathrm{PH}$ in all genotypes was verified under water deficit (Table 2). Among the treatments under stress, in the CNPA 76 AM genotype plant height was higher for the treatment inoculated with SEMIA 6144 followed by ESA 123. The lowest loss of growth was observed in CNPA 76 AM when inoculated with SEMIA $6144(11 \%)$. It is also observed a greater height for the BRS Havana and 2012-4 genotypes when inoculated with the SEMIA 6144 and ESA 123 strains, compared to the other treatments. These results show a positive contribution of bacteria to plant growth under water deficit conditions.

In the treatments under water deficit, SDM was reduced in nine of the 12 evaluated treatments (Table 2). In CNPA 76 AM inoculated with ESA 123 there was the smallest reduction, about $7 \%$ in relation to the irrigated treatment; the highest SDM reduction was observed in the nitrogen treatment, with $57 \%$ reduction in relation to the irrigated treatment. In the BRS Havana genotype, there was a greater height reduction for the plants inoculated with SEMIA 6144 (61\%) and supplemented with mineral nitrogen $(56 \%)$; and the lowest reductions for plants inoculated with ESA 123 (24\%) and absolute control treatment (22\%). For the 2012-4 genotype, the largest SDM reduction was for the treatment without nitrogen (59\%) and the lowest (21\%) for the with ESA 123 inoculation. These variations indicate that, in general, strain ESA 123 was the most efficient in avoiding SDM reductions from plants under stress condition.
RDM was reduced in 11 of the 12 evaluated treatments under water deficit (Table 2). In the CNPA 76 AM genotype there was loss of RDM in three treatments in relation to the irrigated condition. The greatest loss of RDM was observed for the treatment without nitrogen. However, plants inoculated with ESA 123 there was a 44\% increase in RDM. The decrease in RDM for the BRS Havana genotype was higher in plants with nitrogen fertilization (about 54\%) and lower for those inoculated with the ESA 123 strain (32\%) when compared to the treatments under irrigation. For the 2012-4 genotype, there was a maximum reduction of $20 \%$ of RDM for the treatment without nitrogen under water deficit. However, the lowest reductions were observed in the treatments with nitrogen and ESA 123 with $5.1 \%$ and $2.8 \%$, respectively.

The evaluation of NCS showed a decrease in plants submitted to water deficit. Considering the plants which were not submitted to stress, inoculation with the two strains of Bradyrhizobium and the application of mineral $\mathrm{N}$ resulted in the increase of NCS in BRS Havana in relation to the treatment without N. For 2012-4, the treatments did not differentiate, whereas the treatment that received $\mathrm{N}$ mineral stood out. Regarding the treatments submitted or not to water deficit, for the CNPA 76 AM genotype, only the inoculation treatment with ESA 123 did not result in the significant reduction of $\mathrm{N}$ contents in shoot. For 2012-4 genotype, the two inoculation treatments and the nitrogen control did not show NCS reduction. The inoculation treatments influenced peanut genotypes differently when submitted to water stress.

In general, in the evaluated physiological parameters, the inoculation of SEMIA 6144 resulted in activities increase of the two antioxidant enzymes, while the inoculation of ESA 123 resulted in decrease in these values (Table 3). Overall, the inoculation of ESA 123 strain attenuated the effects of water stress on the vegetative development parameters.

\section{Discussion}

Bradyrhizobium strains are the favorite micro-symbionts of peanut and large amounts of nitrogen can be fixed in trials under field conditions (Thies et al. 1991; Valetti et al. 2016). Within the Bradyrhizobium group, peanuts can nodulate with bacteria belonging to the $B$. elkanii clade, such as the commercial strain SEMIA 6144 or the clade B. japonicum, as several isolated strains from the semi-arid region of Brazil (Santos et al. 2017a).

Comparison of the almost complete sequence (1268 nt) of the 16S rRNA gene of strain ESA 123 showed that this isolate is classified within the $B$. japonicum clade with the most similarity to the strain type $14-3^{\mathrm{T}} B$. kavangense. This species has recently been described, isolated from peanut nodules in Namibia (Grönemeyer et al. 2015) and 
$=\mathrm{NS}=\mathrm{WS}$
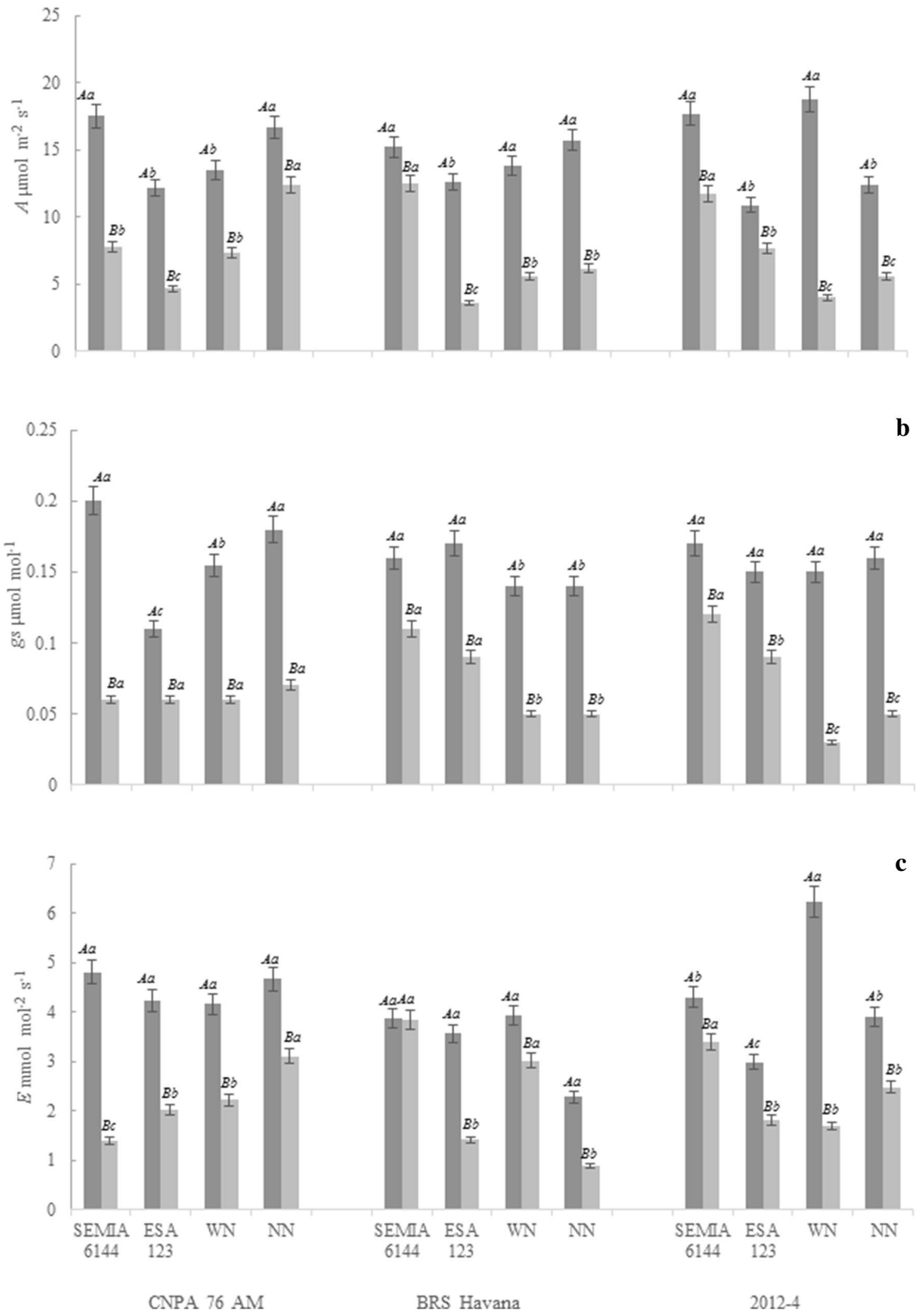
4Fig. 2 Net photosynthesis $(A)(\mathbf{a})$, stomatal conductance $(g s)(\mathbf{b})$ and transpiration $(E)(\mathbf{c})$ on leaves of peanut plants submitted to water deficit and inoculated with two strains of Bradyrhizobium. Upper case letters compare the inoculation treatments in two water regimes in the same genotype (water regime: $N S$ no stress and WS with stress) and lowercase letters for treatments within water regime, with the same genotype (Tukey's test, $p<0.05$ )

bacteria with sequences of the $16 \mathrm{~S}$ rRNA gene related to B. kavangense were later isolated in South Africa (Jaiswal et al. 2017) and in Brazil (Santos et al. 2017a). Although the $16 \mathrm{~S}$ rRNA gene sequence shows high similarity (98.97\%) to B. kavangense, the ESA 123 strain may represent a new species, since the taxonomy of Bradyrhizobium is complex and cannot be elucidated only with the $16 \mathrm{~S}$ rRNA allele (Hungria et al. 2015). Thus, the analysis of other constitutive and symbiotic genes will be necessary to determine exactly to which species this isolate is affiliated.

The inoculation of Bradyrhizobium showed different effects on the peanut varieties, both in the physiological and plant growth parameters. This results variation is expected since there is a strong interaction between the plant genotype and the inoculated bacterium, as already observed for tropical legumes such as cowpea (Marinho et al. 2014, 2017; Alcântara et al. 2014) and peanut (Melo et al. 2016).

The elevation of oxidative stress enzymes activities in plants inoculated with SEMIA 6144 indicates the reduction of highly reactive species such as $\mathrm{H}_{2} \mathrm{O}_{2}$. Cellular $\mathrm{H}_{2} \mathrm{O}_{2}$ reductions in peanut inoculated with the strain SEMIA 6144 have been reported in the literature (Furlan et al. 2012). However, the alteration of enzyme activities in peanut inoculated with this strain has never been reported. The inoculation of the new strain ESA 123 resulted in the reduction of the activity of oxidative stress enzymes in the peanut genotypes, indicating the prevalence of other physiological pathways to reduce the damages of drought, as recently observed in maize inoculated with efficient diazotrophic bacteria at the gene expression level for oxidative stress enzymes encoding genes (Fukami et al. 2017a, b). Although, for corroboration of this hypothesis, the other physiological traits should be in agreement and indicate the higher plant homeostasis.

In addition to the action of enzymes, the accumulation of osmoregulatory substances, as proline for example, can prevent further damage to plant cells under abiotic stress (Azevedo Neto et al. 2010; Marin et al. 2010; Monteiro et al. 2014; Kang et al. 2014). In the present study, the proline content increased in all treatments under water restriction, in all peanut genotypes, as well as observed in noninoculated peanut under water deficit (Pereira et al. 2012; Padmavathi and Rao 2013). The BRS Havana genotype was the only one that presented higher proline content when compared to the treatments with and without $\mathrm{N}$ fertilization.
These results suggest that the presence of $\mathrm{N}$-fixing bacteria in symbiosis with the BRS Havana genotype may have induced a more efficient response of plants subjected to abiotic stress.

The reduction of net photosynthetic activity, as observed for almost all treatments in the present study, is common in peanut under water stress (Kalariya et al. 2013) due to the stomatal closure as a water preservation mechanism. However, in spite of the reduction of photosynthesis and transpiration in the treatments inoculated with rhizobia, the reduction was less accentuated, which is a positive effect of the strains as they are able to promote osmoregulators production and to attenuate the stress effect (Chang et al. 2007). The reduction of $g s$ limits the absorption of $\mathrm{CO}_{2}$ and the photosynthesis and it is necessary to avoid transpiration, since it was reduced in the treatments under water restriction. Kalariya et al. (2013) observed the reduction of $g_{s}$ in peanut varieties when they were submitted to water deficit, observing reductions between 20 and 55\%, without the presence of inoculants. However, in the presence of the strain ESA 123, there was the smaller reduction of $g s$ among the treatments, reinforcing the effects of the symbiotic association with ESA 123 for reducing the drought effects in peanut. The gas exchanges results observed in the plants inoculated with ESA 123 corroborated the hypothesis that peanut plants inoculated with this strain shows other mechanisms to overcome the water deficiency damages.

Higher N content in plants with full water supply, compared to those subjected to water deficit, indicated that in the period of low water availability, the activity of the nodules on nitrogen fixation was reduced or completely stopped. But the inoculation of rhizobia results in other benefits for the hosts, besides the $\mathrm{N}$ fixation (Suárez et al. 2008; Oliveira et al. 2012). These positive effects were observed in the physiological traits evaluated in the present study, indicating that the inoculation of ESA 123 and SEMIA 6144 can benefit the peanuts by other plant growth promoting mechanisms, in addition to $\mathrm{BNF}$, what is important to strain selection for drylands, as the Brazilian semi-arid region. The agronomic efficiency of ESA 123 was already showed in rain-fed field conditions of Brazilian semi-arid (Sizenando et al. 2016). The data obtained in the present study indicated that the high field performance of this bradyrhizobia can be achieved due its higher $\mathrm{N}$ fixation ability in addition to the bacterium influence to increase the drought tolerance of peanut plants.

The rhizobia inoculation reduced the effects of drought in the peanut plants in the present study. Combining the results of lower reduction of leaf gas exchanges, proline accumulation and reduction of SOD and APX enzymes, the average higher plant development and $\mathrm{N}$ accumulation, along with the agronomic efficiency previously evaluated by Sizenando et al. (2016), it is possible to point out the 
Table 1 Means obtained for catalase (CAT), ascorbate peroxidase (APX), proline and percentage for the reduction of enzymatic activity with water stress or with no water stress, for the genotypes CNPA 76 AM, BRS Havana and 2012-4

\begin{tabular}{|c|c|c|c|c|c|c|c|c|c|}
\hline \multirow[t]{2}{*}{ Treatments } & \multicolumn{3}{|c|}{$\begin{array}{l}\text { CAT } \\
\left(\mu \mathrm{mol} \text { of } \mathrm{H}_{2} \mathrm{O}_{2} \mathrm{~min}^{-1} \mathrm{mg}\right. \\
\text { protein }\end{array}$} & \multicolumn{3}{|c|}{$\begin{array}{l}\text { APX } \\
\left(\mu \mathrm{mol} \text { of ASC } \min ^{-1} \mathrm{mg}\right. \\
\left.\text { protein }^{-1}\right)\end{array}$} & \multicolumn{3}{|c|}{$\begin{array}{l}\text { Proline } \\
\left(\mu \mathrm{mol} \mathrm{g}{ }^{-1} \mathrm{MF}\right)\end{array}$} \\
\hline & NS & WS & $(\%)$ & NS & WS & $(\%)$ & NS & WS & $(\%)$ \\
\hline \multicolumn{10}{|l|}{ CNPA 76 AM } \\
\hline SEMIA 6144 & $0.45 \mathrm{Bc}$ & $0.77 \mathrm{Aa}$ & 71 & $14.18 \mathrm{Ba}$ & $19.57 \mathrm{Aa}$ & 38 & $0.19 \mathrm{Ba}$ & $0.28 \mathrm{Aa}$ & 47 \\
\hline ESA 123 & $0.60 \mathrm{Ab}$ & $0.48 \mathrm{Bb}$ & -20 & $26.84 \mathrm{Aa}$ & $20.50 \mathrm{Aa}$ & -24 & $0.15 \mathrm{Aa}$ & $0.16 \mathrm{Ab}$ & 7 \\
\hline $\mathrm{WN}$ & $0.86 \mathrm{Aa}$ & $0.86 \mathrm{Aa}$ & 0 & $16.18 \mathrm{Ba}$ & $16.90 \mathrm{Ba}$ & 4 & $0.16 \mathrm{Ba}$ & $0.28 \mathrm{Aa}$ & 75 \\
\hline $\mathrm{NN}$ & $0.78 \mathrm{Ab}$ & $0.85 \mathrm{Aa}$ & 9 & $24.37 \mathrm{Aa}$ & $15.88 \mathrm{Ba}$ & -35 & $0.21 \mathrm{Aa}$ & $0.29 \mathrm{Aa}$ & 38 \\
\hline \multicolumn{10}{|l|}{ BRS Havana } \\
\hline SEMIA 6144 & $0.64 \mathrm{Bb}$ & $0.86 \mathrm{Ab}$ & 34 & $22.20 \mathrm{Aa}$ & $23.32 \mathrm{Ab}$ & 5 & $0.13 \mathrm{Bb}$ & $0.29 \mathrm{Aa}$ & 123 \\
\hline ESA 123 & $0.57 \mathrm{Ab}$ & $0.33 \mathrm{Bc}$ & -42 & $13.88 \mathrm{Ab}$ & $9.50 \mathrm{Bc}$ & -32 & $0.15 \mathrm{Ba}$ & $0.26 \mathrm{Aa}$ & 73 \\
\hline $\mathrm{WN}$ & $0.75 \mathrm{Aa}$ & $0.34 \mathrm{Bc}$ & -55 & $18.52 \mathrm{Ba}$ & $25.49 \mathrm{Ab}$ & 37 & $0.18 \mathrm{Aa}$ & 0.19Aa & 5 \\
\hline $\mathrm{NN}$ & $0.34 \mathrm{Bc}$ & $1.23 \mathrm{Aa}$ & 262 & $11.85 \mathrm{Bb}$ & $33.52 \mathrm{Aa}$ & 190 & $0.19 \mathrm{Ba}$ & $0.23 \mathrm{Aa}$ & 21 \\
\hline \multicolumn{10}{|l|}{$2012-4$} \\
\hline SEMIA 6144 & $0.71 \mathrm{Ba}$ & $1.15 \mathrm{Aa}$ & 70 & $21.51 \mathrm{Aa}$ & 23.49Aa & 9 & $0.20 \mathrm{Ba}$ & $0.26 \mathrm{Aa}$ & 30 \\
\hline ESA 123 & $0.56 \mathrm{Ba}$ & $0.86 \mathrm{Ab}$ & 53 & $21.87 \mathrm{Aa}$ & $15.91 \mathrm{Bb}$ & -27 & $0.22 \mathrm{Ba}$ & $0.29 \mathrm{Aa}$ & 32 \\
\hline $\mathrm{WN}$ & $0.45 \mathrm{Bb}$ & $0.93 \mathrm{Aa}$ & 106 & $23.50 \mathrm{Aa}$ & $24.82 \mathrm{Aa}$ & 6 & $0.15 \mathrm{Bb}$ & $0.29 \mathrm{Aa}$ & 93 \\
\hline NN & $0.37 \mathrm{Bb}$ & $0.75 \mathrm{Ab}$ & 102 & $21.22 \mathrm{Ba}$ & $25.15 \mathrm{Aa}$ & 18 & $0.13 \mathrm{Bb}$ & $0.30 \mathrm{Aa}$ & 130 \\
\hline
\end{tabular}

Uppercase letters comparing the means in the lines between water regimes and lowercase letters in the columns comparing the treatments within the same water regime (Tukey's test, $p<0.05$ )

$W N$ with $\mathrm{N}, N N$ without $\mathrm{N}, W S$ with stress, $N S$ no stress

\begin{tabular}{|c|c|c|c|c|c|c|c|c|}
\hline \multirow[t]{2}{*}{ Treatments } & \multicolumn{2}{|c|}{$\mathrm{PH}(\mathrm{cm})$} & \multicolumn{2}{|c|}{ SDM (g) } & \multicolumn{2}{|l|}{ RDM (g) } & \multicolumn{2}{|c|}{$\operatorname{NCS}\left(\mathrm{mg} \mathrm{g}^{-1}\right)$} \\
\hline & NS & WS & NS & WS & NS & WS & NS & WS \\
\hline \multicolumn{9}{|l|}{ CNPA 76 AM } \\
\hline SEMIA 6144 & $15.3 \mathrm{Ab}$ & $13.6 \mathrm{Ba}$ & 6.2Aa & $4.8 \mathrm{Ba}$ & $0.261 \mathrm{Ab}$ & $0.170 \mathrm{Bd}$ & $17.42 \mathrm{Aa}$ & $12.55 \mathrm{Ba}$ \\
\hline ESA 123 & $18.1 \mathrm{Aa}$ & $11.5 \mathrm{Ba}$ & $4.6 \mathrm{Ab}$ & 4.3Aa & $0.188 \mathrm{Bc}$ & $0.270 \mathrm{Aa}$ & 14.07Aa & $10.61 \mathrm{Aa}$ \\
\hline WN & $15.3 \mathrm{Ab}$ & $10.7 \mathrm{Ba}$ & 8.2Aa & $3.5 \mathrm{Ba}$ & $0.288 \mathrm{Ab}$ & $0.236 \mathrm{Bb}$ & $22.32 \mathrm{Aa}$ & $9.56 \mathrm{Ba}$ \\
\hline NN & $14.0 \mathrm{Ab}$ & $10.4 \mathrm{Ba}$ & 6.3Aa & $3.7 \mathrm{Ba}$ & $0.347 \mathrm{Aa}$ & $0.229 \mathrm{Bb}$ & 18.51Aa & $8.90 \mathrm{Ba}$ \\
\hline \multicolumn{9}{|l|}{ BRS Havana } \\
\hline SEMIA 6144 & 7.7Aa & $5.6 \mathrm{Ba}$ & 5.6Aa & $2.2 \mathrm{Ba}$ & $0.261 \mathrm{Ab}$ & $0.125 \mathrm{Bb}$ & 12.78Aa & $6.00 \mathrm{Ba}$ \\
\hline ESA 123 & $6.4 \mathrm{Aa}$ & $3.2 \mathrm{Ba}$ & 5.3Aa & $4.0 \mathrm{Ba}$ & $0.271 \mathrm{Ab}$ & $0.185 \mathrm{Ba}$ & $13.72 \mathrm{Aa}$ & 9.72Aa \\
\hline WN & $4.4 \mathrm{Ab}$ & $2.1 \mathrm{Bb}$ & 6.3Aa & $2.8 \mathrm{Ba}$ & $0.350 \mathrm{Aa}$ & $0.164 \mathrm{Ba}$ & $16.32 \mathrm{Aa}$ & $7.85 \mathrm{Ba}$ \\
\hline $\mathrm{NN}$ & $5.3 \mathrm{Aa}$ & $2.6 \mathrm{Bb}$ & 4.1Aa & $3.2 \mathrm{Ba}$ & $0.195 \mathrm{Ac}$ & $0.161 \mathrm{Aa}$ & $10.42 \mathrm{Ab}$ & $8.06 \mathrm{Aa}$ \\
\hline \multicolumn{9}{|l|}{$2012-4$} \\
\hline SEMIA 6144 & $13.3 \mathrm{Aa}$ & $8.4 \mathrm{Ba}$ & 4.4Aa & $3.1 \mathrm{Ba}$ & $0.270 \mathrm{Ab}$ & $0.230 \mathrm{Ab}$ & $12.00 \mathrm{Ab}$ & 7.71 Aa \\
\hline ESA 123 & $12.5 \mathrm{Aa}$ & $11.4 \mathrm{Aa}$ & 4.3Aa & 3.4Aa & $0.250 \mathrm{Ab}$ & $0.243 \mathrm{Ab}$ & $11.35 \mathrm{Ab}$ & 9.40Aa \\
\hline WN & 11.1Aa & $9.2 \mathrm{Ba}$ & 4.2Aa & 3.1Aa & $0.260 \mathrm{Ab}$ & $0.246 \mathrm{Ab}$ & $20.42 \mathrm{Aa}$ & $8.52 \mathrm{Ba}$ \\
\hline $\mathrm{NN}$ & $12.0 \mathrm{Aa}$ & $9.4 \mathrm{Ba}$ & 7.8Aa & $3.2 \mathrm{Ba}$ & $0.371 \mathrm{Aa}$ & $0.296 \mathrm{Ba}$ & $11.79 \mathrm{Ab}$ & $8.04 \mathrm{Aa}$ \\
\hline
\end{tabular}

Uppercase letters comparing the means in the lines between water regimes and lowercase letters in the columns comparing the treatments within the same water regime (Tukey's test, $p<0.05$ )

$W N$ with $\mathrm{N}, N N$ without $\mathrm{N}, W S$ with stress, $N S$ no stress
Table 2 Means for plant height $(\mathrm{PH})$, shoot dry mass (SDM), root dry mass (RDM) and nitrogen content in shoot (NCS) for the genotypes CNPA 76 AM, BRS Havana and 2012-4 new Bradyrhizobium strain ESA 123 as a promising isolate for official recommendation for field inoculation of peanut in Brazilian drylands. Although, further studies are needed to understand the physiological changes induced by ESA 123 in peanuts, as well as, its field evaluation under water deficiency conditions. 
Table 3 Effect of treatments applied on peanut genotypes with or without water deficit

\begin{tabular}{lllllllllll}
\hline Treataments & gs & A & E & CAT & APX & Proline & PH & SDM & RDM & NCS \\
\hline CNPA 76 AM & & & & & & & & & & \\
SEMIA 6144 & $\downarrow$ & $\downarrow$ & $\downarrow$ & $\uparrow$ & $\uparrow$ & $\uparrow$ & $\downarrow$ & $\downarrow$ & $\downarrow$ & $\downarrow$ \\
ESA 123 & $\downarrow$ & $\downarrow$ & $\downarrow$ & $\downarrow$ & $=$ & $=$ & $\downarrow$ & $=$ & $\uparrow$ & $=$ \\
WN & $\downarrow$ & $\downarrow$ & $\downarrow$ & $=$ & $=$ & $\uparrow$ & $\downarrow$ & $\downarrow$ & $\downarrow$ & $\downarrow$ \\
NN & $\downarrow$ & $\downarrow$ & $\downarrow$ & $=$ & $\downarrow$ & $=$ & $\downarrow$ & $\downarrow$ & $\downarrow$ & $\downarrow$ \\
BRS Havana & & & & & & & & & & \\
SEMIA 6144 & $\downarrow$ & $\downarrow$ & $=$ & $\uparrow$ & $=$ & $\uparrow$ & $\downarrow$ & $\downarrow$ & $\downarrow$ & $\downarrow$ \\
ESA 123 & $\downarrow$ & $\downarrow$ & $\downarrow$ & $\downarrow$ & $\downarrow$ & $\uparrow$ & $\downarrow$ & $\downarrow$ & $\downarrow$ & $=$ \\
WN & $\downarrow$ & $\downarrow$ & $\downarrow$ & $\downarrow$ & $\uparrow$ & $=$ & $\downarrow$ & $\downarrow$ & $\downarrow$ & $\downarrow$ \\
NN & $\downarrow$ & $\downarrow$ & $\downarrow$ & $\uparrow$ & $\uparrow$ & $\uparrow$ & $\downarrow$ & $\downarrow$ & $=$ & $=$ \\
2012-4 & & & & & & & & & & \\
SEMIA 6144 & $\downarrow$ & $\downarrow$ & $\downarrow$ & $\uparrow$ & $=$ & $\uparrow$ & $\downarrow$ & $\downarrow$ & $=$ & $=$ \\
ESA 123 & $\downarrow$ & $\downarrow$ & $\downarrow$ & $\uparrow$ & $\downarrow$ & $\uparrow$ & $=$ & $=$ & $=$ & $=$ \\
WN & $\downarrow$ & $\downarrow$ & $\downarrow$ & $\uparrow$ & $=$ & $\uparrow$ & $\downarrow$ & $=$ & $=$ & $\downarrow$ \\
NN & $\downarrow$ & $\downarrow$ & $\downarrow$ & $\uparrow$ & $\uparrow$ & $\uparrow$ & $\downarrow$ & $\downarrow$ & $\downarrow$ & $=$ \\
\hline
\end{tabular}

Increases, reductions or lack of effects were reported according to the statistical significance of mean comparisons (Tukey's test $p>0.05$ )

$W N$ with $\mathrm{N}, N N$ without $\mathrm{N}$

\section{Conclusion}

The inoculation of Bradyrhizobium strains, specially the new strain ESA 123, native from the semi-arid region, reduces the damages caused by water deficit in Brazilian peanut genotypes.

Acknowledgements To Embrapa (Brazilian Agricultural Research Corporation) (03.16.05.016.00.00) for the financial support. To Coordination of Improvement of Higher Education Personnel (CAPES) for the scholarships granted to the first and second authors. We thank Dr. Taís Suassuna by supply of the peanut seeds.

\section{Compliance with ethical standards}

Conflict of interest The authors declare that they have no conflict of interest.

\section{References}

Alcântara RMCM, Xavier GR, Rumjanek NG, Rocha MM, Carvalho JS (2014) Eficiência simbiótica de progenitores de cultivares brasileiras de feijão-caupi. Rev Cienc Agron 45:1-9. https://doi. org/10.1590/S1806-66902014000100001

Azevedo RA, Alas RM, Smith RJ, Lea PJ (1998) Response of antioxidant enzymes to transfer from elevated carbon dioxide to air and ozone fumigation, in the leaves and roots of wild-tipe and a catalase-deficient mutant of barley. Physiol Plant 104:280-292. https://doi.org/10.1034/j.1399-3054.1998.1040217.x

Azevedo Neto AD, Nogueira RJMC, Melo Filho PA, Santos RC (2010) Physiological and biochemical responses of peanut genotypes to water deficit. J Plant Interact 5:1-10. https://doi. org/10.1080/17429140902999243
Barbosa MR, Silva MMA, Willadino L, Ulisses C, Camara TR (2014) Geração e desintoxicação enzimática de espécies reativas de oxigênio em plantas. Cienc Agrar 44:453-460. https://doi. org/10.1590/S0103-84782014000300011

Bates L, Waldren RP, Teare ID (1973) Rapid determination of free proline for water-stress studies. Plant Soil 39:205-207. https:// doi.org/10.1007/BF00018060

Bradford JM (1976) A rapid and sensitive method for quantification of microgram quantities of protein utilizing the principle of protein-dye binding. Anal Biochem 72:248-254. https://doi. org/10.1016/0003-2697(76)90527-3

Chang WS, Van De Mrotel M, Nielsen L, Guzman GN, Li X, Halverson LJ (2007) Alginate production by Pseudomonas putida creates a hydrated microenvironment and contributes to biofilm architecture and stress tolerance under water-limiting conditions. J Bacteriol 189:8290-8299. https://doi.org/10.1128/JB.00727-07

Chaves ARM, Aidar ST (2013) Adaptação de protocolo para a extração de enzimas antioxidantes em folhas de plantas lenhosas. Embrapa Semiárido, Embrapa Semiárido, Comunicado Técnico, Petrolina

CONAB - Companhia Nacional de Abastecimento (2017) Acompanhamento da Safra Brasileira: Grãos. Boletim informativo. Nono Levantamento Safra 2016, Brasília

EMBRAPA - EMPRESA BRASILEIRA DE PESQUISA AGROPECUÁRIA (1997) Manual de métodos de análises de solo. 2 edn. Ministério da Agricultura e do Abastecimento, Rio de Janeiro

Farooq M, Wahid A, Kobayashi N, Fujita D, Basra SMA (2009) Plant drought stress: effects, mechanisms and management. Agron Sustain Dev 29:185-212. https://doi.org/10.1051/agro:2008021

Fernandes-Júnior PI, Aidar ST, Morgante CV, Gava CAT, Zilli JE, Souza LSB, Marinho RCN, Nóbrega RSA, Brasil MS, Seido SL, Martins LMV (2015) The resurrection plant Tripogon spicatus (Poaceae) harbors a diversity of plant growth promoting bacteria in northeastern Brazilian Caatinga. Rev Bras Cienc Solo 39:9931002 https://doi.org/10.1590/01000683rbcs20140646

Ferreira DF (2011) Sis Var® (Software estatístico): sistema de análise de variância para dados balanceados, versão 5.6 Lavras: DEX/ UFLA https://www.scienceopen.com/document?vid=80384cd5fe4c-49f7-80d7-beb3e1f0958b. Accessed 16 Aug 2014 
Fukami J, La Osa C, Ollero FJ, Megías M, Hungria M (2017a) Coinoculation of maize with Azospirillum brasilense and Rhizobium tropici as a strategy to mitigate salinity stress. Funct Plant Biol 45:328-339. https://doi.org/10.1071/FP17167

Fukami J, Ollero FJ, Megías M, Hungria M (2017b) Phytohormones and induction of plant-stress tolerance and defense genes by seed and foliar inoculation with Azospirillum brasilense cells and metabolites promote maize growth. AMB Express 7:153. https://doi.org/10.1186/s13568-017-0453-7

Furlan A, Llanes A, Luna V, Castro S (2012) Physiological and biochemical responses to drought stress and subsequent rehydration in the symbiotic association peanut-Bradyrhizobium sp.. ISRN Agron. https://doi.org/10.5402/2012/318083

Grönemeyer JL, Hurek T, Reinhold-Hurek B (2015) Bradyrhizobium kavangense sp. nov., a symbiotic nitrogen-fixing bacterium from root nodules of traditional namibian pulses. Int J Syst Evol Microbiol 65:4886-4894 https://doi.org/10.1099/ijsem.0.00066 6

Hungria M, Menna P, Delamuta JRM (2015) Bradyrhizobium, the ancestor of all rhizobia: phylogeny of housekeeping and nitrogen-fixation genes. In: de Bruijn FR (ed) Biological nitrogen fixation, 1st edn. Wiley, Hoboken, pp. 191-202. https://doi. org/10.1002/9781119053095.ch18

Jaiswal SK, Msimbira LA, Dakora FD (2017) Phylogenetically diverse group of native bacterial symbionts isolated from root nodules of groundnut (Arachis hypogaea L.) in South Africa. Syst Appl Microbiol 40:215-226 https://doi.org/10.1016/j.syapm .2017.02.002

Kalariya KA, Singh AL, Chakraborty K, Zala PV, Patel C (2013) Photosynthetic characteristics of groundnut (Arachis hypogaea L.) under water deficit stress. Indian J Plant Physiol 18:157-163. https ://doi.org/10.1007/2Fs40502-013-0027-x

Kang G, Li G, Guo T (2014) Molecular mechanism of salicylic acidinduced abiotic stress tolerance in righer plants. Acta Physiol Plant 36:2287-2297. https://doi.org/10.1007/2Fs11738-014-1603-Z

Kavamura VN, Santos SN, Silva JL, Parma MM, Avila LA, Visconti A, Zucchi TD, Taketani RG, Andreote FD, Melo IS (2013) Screening of Brazilian cacti rhizobacteria for plant growth promotion under drought. Microbiol Res 168:183-191. https://doi.org/10.1016/j. micres.2012.12.002

Kim YH, Kwak SS (2010) The role of antioxidant enzymes during leaf development. In: Gupta SD (ed) Reactive oxygen species and antioxidants in higher plants. Science Publishers, Enfield, pp 129-150

Liao CFH (1981) Devarda's alloy method for total nitrogen determination. Soil Sci Soc Am J 45:852-855. https://doi.org/10.2136/sssaj $1981.03615995004500050005 x$

Lyra MCCP, Freitas ADS, Silva TA, Santos CERS. (2013) Phenotypic and molecular characteristics of rhizobia isolated from nodules of peanut (Arachis hypogaea L.) grown in Brazilian Spodosols. Afr J Biotechnol 12:2147-2156. https://doi.org/10.5897/AJB11.1574

Magalhães Filho JR, Amaral LR, Machado DFSP, Medina CL, Machado EC (2008) Deficiência hídrica, trocas gasosas e crescimento de raízes em laranjeira 'valência' sobre dois tipos de portaenxerto. Bragantia 67:75-82. https://doi.org/10.1590/S0006 $-87052008000100009$

Maia PSP, Oliveira Neto CF, Castro DS, Freitas JMN, Lobato AKS, Costa RCL (2007) Conteúdo relativo de água, teor de prolina e carboidratos solúveis totais em folhas de duas cultivares de milho submetidas a estresse hídrico. Rev Bras Biocienc 5:918-920

Marin JA, Andreu P, Carrasco A, Arbeloa A (2010) Determination of proline concentration, an abiotic stress marker, in root exudates of excised root cultures of fruit tree rootstocks under salt stress. Revue des Régions Arides 24:722-727

Marinho RCN, Nóbrega RSA, Zilli J, Xavier GR, Santos CAF, Aidar ST, Martins LMV, Fernandes Júnior PI (2014) Field performance of new cowpea cultivars inoculated with efficient nitrogen-fixing rhizobial strains in the Brazilian Semiarid. Pesq Agropec Bras 49:395-402. https://doi.org/10.1590/S0100-204X2014000500009

Marinho RCN, Ferreira LVM, Silva AF, Martins LMV, Nóbrega RSA, Fernandes-Júnior PI (2017) Symbiotic and agronomic efficiency of new cowpea rhizobia from Brazilian Semi-Arid. Bragantia 76:273-281. https://doi.org/10.1590/1678-4499.003

Marques DJ, Broetto F, Silva EC (2010) Concentração de prolina em folhas de plantas de berinjela cultivadas sobre condições de salinidade. Hort Bras 28:S853-S858

Melo EBS, Lima LM, Fernandes Junior PI, Aidar ST, Freire MAO, Freire RMM, Santos RC (2016) Nodulation, gas exchanges and production of peanut cultivated with Bradyrhizobium in soils with different textures. Comun Sci 7:160-166. https://doi.org/10.14295 /CS.v7i2.1449

Monteiro JG, Cruz FJR, Nardin MB, Santos DMM (2014) Crescimento e conteúdo de prolina em plântulas de guandu submetidas a estresse osmótico e à putrescina exógena. Pesq Agropec Bras 49:18-25. https://doi.org/10.1590/S0100-204X2014000100003

Nakano Y, Asada K (1981) Hydrogen peroxide is scavenged by ascorbato-specific peroxidase in spinach chloroplasts. Plant Cell Physiol 22:867-880. https://doi.org/10.1093/oxfordjournals.pcp. a076232

Oliveira MT, Benko-Iseppon A, Kido EA, Santos MG (2012) Leaf photosynthetic metabolism and $\mathrm{N}_{2}$ fixation at the flowering stage in three genotypes of cowpea [Vigna unguiculata (L.) Walp.]. J Agric Sci 4:245-256. https://doi.org/10.5539/jas.v4n2p245

Padmavathi TAV, Rao DM (2013) Differential accumulation of osmolytes in 4 cultivars of peanut (Arachis hypogaea L.) under drought stress. J Crop Sci Biotechnol 16:151-159. https://doi. org/10.1007/s12892-012-0102-2

Patra RK, Pant LM, Pradhan K (2012) Response of soybean to inoculation with rhizobial strains: effect on growth, yield, $\mathrm{N}$ uptake and soil N status. World J Agric Sci 8:51-54

Pereira JWL, Melo Filho PA, Albuquerque MB, Nogueira RM, Santos RC (2012) Mudanças bioquímicas em genótipos de amendoim submetidos a déficit hídrico moderado. Rev Ciênc Agron 43:766-773

Ribeiro ILAC. (2010) Proteômica de cana-de-açúcar em condição de estresse hídrico. Dissertation, Universidade Federal de Pernambuco, Recife

Santos RC, Freire RMM, Suassuna TF, Rego GM (2006) BRS Havana: nova cultivar de amendoim de pele clara. Pesq Agropec Bras 41:1337-1339

Santos CERS, Silva VSG, Freitas ADS, Silva AF, Bezerra RV, Lyra MCCP, Ferreira JS (2017a) Prospecting of efficient rhizobia for peanut inoculation in a planosol under different vegetation covers. Afr J Microbiol Res 11:123-131. https://doi.org/10.5897/AJMR2 016.8355

Santos JWM, Silva JF, Ferreira TDS, Dias MAM, Fraiz ACR, Escobar IEC, Santos RC, Lima LM, Morgante CV, Fernandes-Júnior PI (2017b) Molecular and symbiotic characterization of peanut bradyrhizobia from the semi-arid region of Brazil. Appl Soil Ecol 121:177-184. https://doi.org/10.1016/j.apsoil.2017.09.033

Shameer S, Prasad TNVKV. (2018) Plant growth promoting rhizobacteria for sustainable agricultural practices with special reference to biotic and abiotic stresses. Plant Growth Regul 84:603-615. https://doi.org/10.1007/s10725-017-0365-1

Sizenando CIT, Ramos JPC, Fernandes-Junior PI, Lima LM, Freire RMM, Santos RC (2016) Agronomic efficiency of Bradyrhizobium in peanut under different environments in Brazilian Northeast. Afr J Agric Res 11:3482-3487. https://doi.org/10.5897/ AJAR2016.11294

Soares MAS, Machado OLT (2007) Defesa de plantas: sinalização química e espécies reativas de oxigênio. Rev Tróp Agr Biol 1:9

Suárez R, Wong A, Ramírez M, Barraza A, Orozco MDC, Cevallos MA, Lara M, Hernández G, Iturriaga G (2008) Improvement of 
drought tolerance and grain yield in common bean by overexpressing trehalose-6-phosphate synthase in rhizobia. Mol Plant Microb Interact 21:958-966 https://doi.org/10.1094/MPMI-21-7-0958

Tamura K, Stecher G, Peterson D, Filipski A, Kumar S (2013) MEGA6: molecular evolutionary genetics analysis version 6.0. Mol Biol Evol 30:2725-2729. https://doi.org/10.1093/molbev/mst197

Thies JE, Singleton PW, Bohlool BB (1991) Influence of the size of indigenous rhizobial populations on establishment and symbiotic performance of introduced rhizobia on field grown legumes. Appl Environ Microbiol 57:19-28

Torres-Júnior CV, Leite J, Santos CERS, Fernandes-Júnior PI, Zilli J, Rumjanek NG, Xavier GR (2014) Diversity and symbiotic performance of peanut rhizobia from Southeast region of Brazil. Afr J Microbiol Res 8:566-577. https://doi.org/10.5897/AJMR2 013.5883

Valetti L, Angelini JG, Taurian T, Ibáñez FJ, Muñoz VL, Anzuay MS, Ludueña LM, Fabra A (2016) Development and field evaluation of liquid inoculants with native bradyrhizobial strains for peanut production. Afr Crop Sci J 24:1-13. https://doi.org/10.4314/acsj. v24i1.1

Vincent JM (1970) A manual for the practical study of root-nodule bacteria. IBP Handbook No 15, Blackkwell Science Publication, Oxford, p. 164

Weisburg WG, Barns SM, Pelletier DA, Lane DJ (1991) 16S ribosomal DNA amplification for phylogenetic study. J Bacteriol 173:697703. https://doi.org/10.1128/jb.173.2.697-703

Yoon SH, Ha SM, Kwon S, Lim J, Kim Y, Seo H, Chun J (2017) Introducing EzBioCloud: a taxonomically united database of $16 \mathrm{~S}$ rRNA and whole genome assemblies. Int J Syst Evol Microbiol 67:1613-1617. https://doi.org/10.1099/ijsem.0.001755

Zahran HH (1999) Rhizobium-legume symbiosis and nitrogen fixation under severe conditions and in an arid climate. Microbiol Mol Biol Rev 63:968-989 